\title{
The Impacts of Behavioral Factors on Social Media Addiction
}

\author{
Gönül Zeynep SAVACI*1 (D) Birgül KUTLU² (D) Çağla ÖZEN³ (D) \\ ${ }^{1}$ Boğaziçi University, Graduate School of Social Sciences, İstanbul, Turkey, zeynepsavaci@gmail.com \\ ${ }^{2}$ Boğaziçi University, School of Applied Sciences, İstanbul, Turkey, birgul.kutlu@boun.edu.tr \\ ${ }^{3}$ Yeditepe University, Faculty of Commerce, İstanbul, Turkey, cagla.ozen@yeditepe.edu.tr \\ * Corresponding Author: cagla.ozen@yeditepe.edu.tr
}

\begin{tabular}{|c|c|}
\hline Article Info & Abstract \\
\hline & $\begin{array}{l}\text { Social media has started to play a crucial role in people's lives. } \\
\text { However, excessive social media usage can bring with social media } \\
\text { addiction that causes failure in different aspects of people's lives }\end{array}$ \\
\hline Received: 22 October 2021 & such as academic life, business life, and even in private life. The \\
\hline Accepted: 13 December 2021 & $\begin{array}{l}\text { main aim of the present study is to discover the impacts of specific } \\
\text { behavioral factors, which are openness, loneliness, self-esteem, life } \\
\text { satisfaction, creativity, stress, neuroticism, social intelligence, and }\end{array}$ \\
\hline $\begin{array}{l}\text { Keywords: Social media, social } \\
\text { media addiction, behavioral factors }\end{array}$ & $\begin{array}{l}\text { narcissism, on social media addiction. A survey was conducted with } \\
506 \text { participants. The results of these analyses showed that while } \\
\text { demographical factors which were gender, marital status, age, and }\end{array}$ \\
\hline doi $10.18009 /$ jcer. 1013726 & $\begin{array}{l}\text { education level affected social media addiction, income status and } \\
\text { occupation had no influence on social media addiction. Moreover, } \\
\text { positive relationships between openness and creativity, openness }\end{array}$ \\
\hline Publication Language: English & $\begin{array}{l}\text { and self-esteem, self-esteem and life satisfaction, loneliness and } \\
\text { neuroticism, and negative relationships between self-esteem and } \\
\text { neuroticism, life satisfaction and stress were detected. }\end{array}$ \\
\hline
\end{tabular}

open 2 access CrossMark (c)

To cite this article: Savacl, G.Z., Kutlu, B. \& Özen, Ç. (2021). The impacts of behavioral factors on social media addiction. Journal of Computer and Education Research, 9 (18), 1059-1083. DOI: 10.18009/jcer.1013726

\section{Introduction}

Nowadays, technology has become an integral part of our lives because almost every person is dependent on technology and technology usage has been increasing gradually. For example, while there were only one million applications available in the Google Play Store in July 2013, there were three and a half million applications as of December 2017 (Statista, 2018). The improvement in technology can help a faster and healthier way of communication. Therefore, in the digital age, it is impossible to deny the central significance of computers and the Internet, as well as the prominent role social media plays (Kirik, Arslan, Cetinkaya, \& Gul, 2015). Social Networking Sites (SNSs) like Facebook provide users to interact with other people free of charge, people show a tendency to use these social media platforms (Satici, 2019). The number of those who use social networks across the globe exceeded two billion by August 2016 and it is estimated to increase up to approximately 
three and a half billion by 2022 which is almost forty percent of the human population in the world (Appel, Grewal, Hadi, \& Stephen, 2019).

On the other hand, users should be careful about how much time they spend on online platforms, since problematic usage of SNSs might cause some diseases as well as social media addiction (Jaradat \& Atyeh, 2017). Unfortunately, smartphone and social media addiction is a rising problem (Arslan, 2020; Montag et al., 2015; Ozer, 2020) which brings with most of the symptoms of behavioral addiction like tolerance, withdrawal, conflict, salience, relapse, mood modification (Hawi \& Samaha, 2017), and phubbing (Cizmeci, 2017). The reasons for problematic social media usage need to be addressed to deal with social media addiction. Several demographic factors like gender, age, and behavioral factors such as loneliness, extraversion, self-esteem, life satisfaction, etc. can have an impact on social media addiction. For example, research by Hardie and Tee (2007) showed that addicted or extreme users were less extraverted and more neurotic than the average users. This means that characteristics of people also might alter the degree of social media addiction.

\section{Aim of the Study}

The main purpose of this study is to examine the impacts of specific behavioral factors which are loneliness, openness, life satisfaction, self-esteem, narcissism, neuroticism, creativity, social intelligence, and stress on social media addiction.

\section{Literature Review}

Social media involves cooperative works as well as Wikipedia, web-logs like WordPress, context groups such as Flickr, SNSs like Instagram and cyber world as Second Life (Kircaburun \& Griffiths, 2018). Social media platforms provide many diverse opportunities for users such as "identifying with others and gaining a sense of belonging; finding a basis for conversation and social interaction; connecting with family, friends, and society; and gaining insight into the circumstances of others" (Valenzuela, Park, \& Kee, 2009). Almost everyone tends to use social media to meet their integration and social interaction needs (Valenzuela et al., 2009). Social media addiction will remain as a major concern due to the constant growth of smartphone and tablet ownership, development of new technologies and substantial enhancement of applications (Hawi \& Samaha, 2017). Lee (2006) cited in Kwon, Kim, Cho and Yang (2013) claims that by definition, addiction meant just drug or substance misuse in the past. However, in today's world, the word addiction represents both drug, substance, gambling, games, or Internet. 
Table 1. Factors affecting social media addiction

\begin{tabular}{|c|c|c|c|}
\hline Dependent Variable & Authors & Positive Associations & Negative Associations \\
\hline \multirow[t]{10}{*}{ Internet Addiction } & $\begin{array}{l}\text { (Bozoglan, Demirer, \& Sahin, } \\
\text { 2013) }\end{array}$ & Loneliness & Self-Esteem \\
\hline & (Cao \& Su, 2007) & $\begin{array}{l}\text { Neuroticism, } \\
\text { Psychoticism, Lie, } \\
\text { Emotional Symptoms, } \\
\text { Problems, Hyperactivity }\end{array}$ & $\begin{array}{l}\text { Sense of Control Over } \\
\text { Time, Value Time, } \\
\text { Time Efficacy }\end{array}$ \\
\hline & (Hardie \& Tee, 2007) & $\begin{array}{l}\text { Loneliness, Neuroticism, } \\
\text { Social Anxiety }\end{array}$ & Extraversion \\
\hline & Johansson and Gotestam, 2004 & $\begin{array}{l}\text { Financial and Work- } \\
\text { Related Problems }\end{array}$ & \\
\hline & (Kim \& Davis, 2009) & Anxiety & Self-Esteem \\
\hline & $\begin{array}{l}\text { (Niemz, Griffiths, \& Banyard, } \\
\text { 2005) }\end{array}$ & & Self-Esteem \\
\hline & (Savci \& Aysan, 2017) & $\begin{array}{l}\text { Social Anxiety, Self- } \\
\text { Censor }\end{array}$ & Self-Monitoring \\
\hline & Whang, Lee and Chang, 2003 & Stress, Loneliness & \\
\hline & $\begin{array}{l}\text { (Yen, Ko, Yen, Wu, \& Yang, } \\
\text { 2007) }\end{array}$ & $\begin{array}{l}\text { ADHD Symptoms, } \\
\text { Depression, Social Phobia, } \\
\text { Hostility }\end{array}$ & \\
\hline & (Young \& Rodgers, 1998) & & $\begin{array}{l}\text { Abstract Thinkers, } \\
\text { Sensitive, Vigilant, } \\
\text { Private Individuals }\end{array}$ \\
\hline \multirow[t]{10}{*}{$\begin{array}{l}\text { Social Media } \\
\text { Addiction }\end{array}$} & (Andreassen et al., 2016) & $\begin{array}{l}\text { ADHD, OCD, Anxiety, } \\
\text { Depression, Gender } \\
\text { (Female), Marital Status } \\
\text { (Single) }\end{array}$ & Age \\
\hline & $\begin{array}{l}\text { (Casale, Rugai, \& Fioravanti, } \\
\text { 2018) }\end{array}$ & $\begin{array}{l}\text { Positive Metacognitions, } \\
\text { Fear of Missing Out, low } \\
\text { Self-Presentational Skills }\end{array}$ & \\
\hline & (Hawi \& Samaha, 2017) & & Self-Esteem \\
\hline & (Jaradat \& Atyeh, 2017) & Extraversion, Openness & Neuroticism \\
\hline & (Khan et al., 2016) & $\begin{array}{l}\text { Non-Compliance Attitude } \\
\text { of Patients }\end{array}$ & \\
\hline & (Kircaburun et al., 2018) & & $\begin{array}{l}\text { Self-Confidence, } \\
\text { Self/Everyday } \\
\text { Creativity }\end{array}$ \\
\hline & (Kirik et al., 2015) & $\begin{array}{l}\text { Daily Spent Time and } \\
\text { Frequency of Visiting SNS }\end{array}$ & Age (18) \\
\hline & (Longstreet \& Brooks, 2017) & & Life Satisfaction \\
\hline & $\begin{array}{l}\text { (Sriwilai \& } \\
\text { Charoensukmongkol, 2016) }\end{array}$ & $\begin{array}{l}\text { Stress, Emotional } \\
\text { Exhaustion }\end{array}$ & Mindfulness \\
\hline & $\begin{array}{l}\text { (Priyadarshana, Yatigammana, } \\
\text { \& Sarathchandra, 2017) }\end{array}$ & $\begin{array}{l}\text { Social Interaction, } \\
\text { Entertainment, } \\
\text { Communication } \\
\end{array}$ & \\
\hline \multirow[t]{2}{*}{ Facebook Addiction } & (Casale \& Fioravanti, 2018) & Narcissism & \\
\hline & (Satici, 2019) & Loneliness, Shyness & \\
\hline Instagram Addiction & (Kircaburun \& Griffiths, 2018) & & $\begin{array}{l}\text { Agreeableness } \\
\text { Conscientiousness }\end{array}$ \\
\hline \multirow[t]{3}{*}{ Internet Usage } & $\begin{array}{l}\text { (Amichai-Hamburger \& Ben- } \\
\text { Artzi, 2003) }\end{array}$ & Loneliness & \\
\hline & (Khan, Rahman \& Qazi, 2016) & Income & Age \\
\hline & (Stepanikova, Nie, \& He., 2010) & Loneliness & Life Satisfaction \\
\hline Social Media Usage & $\begin{array}{l}\text { (Correa, Hinsley, \& De Zuniga, } \\
\text { 2010) }\end{array}$ & Extraversion, Openness & Emotional Stability \\
\hline
\end{tabular}




\begin{tabular}{llll}
\hline & (Hamid, Ishak, \& Yazam, 2015) & Extraversion & \\
\cline { 2 - 4 } & (Liu \& Baumeister, 2016) & Narcissism, Loneliness & Self-Esteem \\
\cline { 2 - 4 } & (Vogel, Rose, Roberts, \& Eckles, & & Self-Esteem \\
2014) & (Valenzuela et al., 2009) & Life Satisfaction, Social & \\
\hline Facebook Usage & Trust, Civic Engagement, \\
& & Political Participation & \\
\hline
\end{tabular}

The reason for calling excessive use of Internet as addiction is that its consequences like failure in academic, working, social or even in private life resemble results of chemical substance addiction (Johansson \& Gotestam, 2004). Internet addiction cogently is associated with gaming and social media (Van den Ejinden, Lemmens, \& Valkenburg, 2016). Therefore, social media addiction might be accepted as a subcategory of excessive Internet usage (Jaradat \& Atyeh, 2017). Thus, social media addiction shows similarity with generalized Internet addiction (Montag et al., 2015).

There are a lot of demographic and behavioral factors which can trigger social media addiction. Table 1 shows some of the factors in literature which are positively or negatively associated with Internet or social media addiction. For example, according to Andreassen et al. (2016), women, single or young people showed more tendency to excessive social media usage. Stepanikova and colleagues (2010) found that Internet addiction and life satisfaction were negatively correlated. The results of research by Hawi and Samaha (2017) showed that people with low self-esteem tend to utilize more social media tools to improve their selfimage and esteem. However, the impacts of some factors such as to be extravert is a controversial issue in literature. Hardie and Tee (2007) found that extravert people spend less time on online platforms. On the other hand, extraversion is positively correlated with social networking sites addiction (Hamid et al., 2015; Jaradat \& Atyeh, 2017). In fact, both being extravert and being introvert can lead to social media addiction because of different usage purposes and reasons. While extravert people use social media to strengthen their relationships, introvert people show tendency to use SNSs to make friends (Kircaburun \& Griffiths, 2018). There are many reasons for social media addiction, but their impacts are debated. 


\section{Method}

\section{Theoretical Model}

Theoretical model of present study (Figure 1) contains five independent variables which are openness, loneliness, stress, social intelligence and narcissism, four intervening variables which are creativity, self-esteem, neuroticism and life satisfaction, and one dependent variable which is social media addiction. All the correlations between factors and social media addiction were examined based on literature. However, there is no model like this which covers all these factors. Therefore, this model is a new model to understand the effects of specific behavioral factors upon social media addiction.

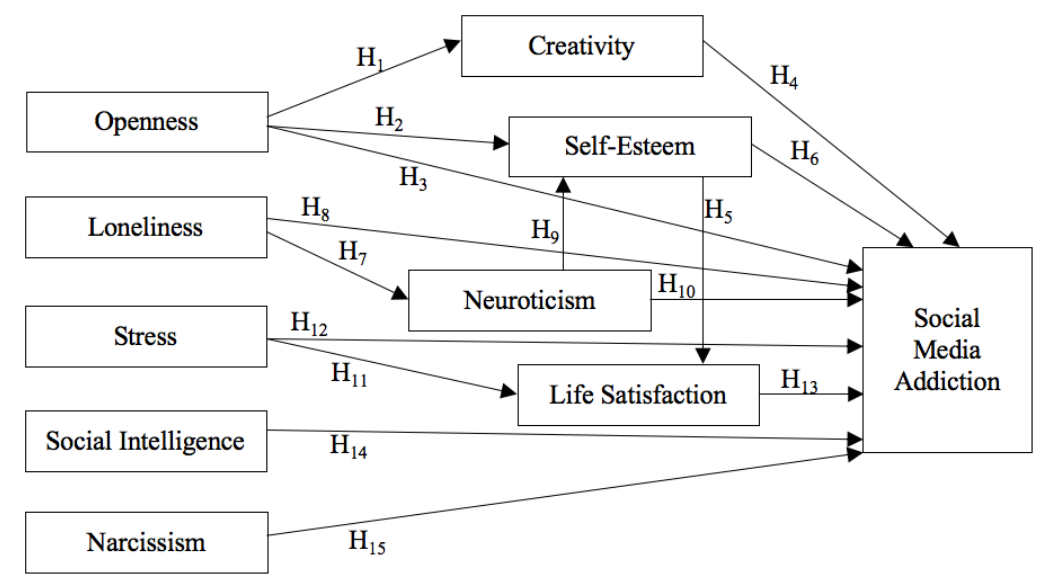

Figure 1. Theoretical framework

Hypotheses

a. Openness

Openness increases both self-esteem (Amirazodi \& Amirazodi, 2011) and creativity (King, McKee Walker, \& Broyles, 1996). Moreover, positive relationship between openness, and experience and SNS usage was detected (Correa et al., 2010). In this model, openness is an independent variable.

H1: Openness has a significant positive impact on creativity.

H2: Openness has a significant positive impact on self-esteem.

H3: Openness has a significant impact on social media addiction.

\section{b. Creativity}

Creativity is a controversial issue. While Lee and Hong (2016) argue that creativity makes a great contribution to social media use, Kircaburun and colleagues (2018) support that there is a negative relationship. In this model, creativity was taken as an intervening variable. 
H4: Creativity has a significant impact on social media addiction.

c. Self-esteem

Self-esteem is one of the major factors which plays an important role in life satisfaction (Hawi \& Samaha, 2017). According to Bozoglan and friends (2013), low selfesteem causes problematic social media use. In this model, self-esteem is an intervening factor.

H5: Self-esteem has a significant positive impact on life satisfaction.

H6: Self-esteem has a significant negative impact on social media addiction.

d. Loneliness

Lonely people tend to use excessive Internet (Engelberg \& Sjoberg, 2004) and they are prone to be neurotic (Mund \& Neyer, 2019). In this model, loneliness is an independent variable.

H7: Loneliness has a significant positive impact on neuroticism.

H8: Loneliness has a significant positive impact on social media addiction.

e. Neuroticism

Neuroticism can cause lower self-esteem (Amirazodi \& Amirazodi, 2011). According to Cao and Su (2007), neuroticism also increases social media addiction. In this model, neuroticism is an intervening variable.

H9: Neuroticism has a significant negative impact on self-esteem.

H10: Neuroticism has a significant positive impact on social media addiction.

f. Stress

Stress is one of the fundamental factors affecting life satisfaction (Longstreet \& Brooks, 2017). Besides, people spend time on social media platforms to handle stress (Sriwilai \& Charoensukmongkol, 2016). In this model, stress is an independent variable.

H11: Stress has a significant negative impact on life satisfaction.

H12: Stress has a significant positive impact on social media addiction.

\section{g. Life Satisfaction}

Longstreet and Brooks (2017) claim that high level of life satisfaction reduces time spending on SNSs. In this model, life satisfaction is an intervening variable.

H13: Life satisfaction has a significant negative impact on social media addiction.

h. Social Intelligence

Social intelligence represents how people construe attitudes of other people, how people manage their private and public relationships, and how much they show empathy towards others (Baron-Cohen et al., 1999). Although in the literature, there is not much 
research about the impacts of social intelligence on social media addiction, as a new research subject, it can be argued that social intelligence may play a crucial role on social media addiction. In this model, social intelligence is an independent variable.

H14: Social intelligence has a significant impact on social media addiction.

i. Narcissism

According to many studies, narcissist people show tendency to use social media excessively (Andereassen et al., 2016; Casale \& Fioravanti, 2018; Hawi \& Samaha, 2017). In this model, narcissism was included as an independent variable.

H15: Narcissism has a significant positive impact on social media addiction.

Six hypotheses were created to measure the impacts of demographical factors and two hypotheses were created to understand social media usage habits of the participants.

H16: There is a significant difference between females and males in terms of social media addiction.

H17: There is a significant difference between single and married participants in terms of social media addiction.

H18: There is a significant difference among different age groups of participants in terms of social media addiction.

H19: There is a significant difference among different education levels of participants in terms of social media addiction.

H20: There is a significant difference among different income levels of participants in terms of social media addiction.

H21: There are significant differences among different occupational groups of participants in terms of social media addiction.

H22: There is a positive correlation between daily spending times of participants on social networking sites and social media addiction level of the participants.

H23: There is a positive correlation between how many times participants check their social media accounts and their social media addiction level.

\section{Participants}

A survey was conducted, and convenience sampling method was used to select the participants. The survey was sent to people as a link via social media platforms which were Facebook and LinkedIn. Participants filled out the survey anonymously. In total 862 people participated in the survey, but not all of them completed. After incomplete and missing data 
containing surveys were excluded, responses of 506 participants were included in the analysis.

\section{Instruments \& Data Analysis}

The questionnaire consisted of 20 questions (see Appendix). First two questions were related to which social networking sites are usually used. Third and fourth questions aimed to understand daily social media usage duration of the participants (Genc, 2015), and the number of participants' social media account checks (Wang, Niiya, Mark, Reich, \& Warschauer, 2015). Last six questions were intended to gain general demographical information about the respondents. Other questions were directly retrieved from the literature to measure the variables of this study.

In the present study, Bergen's Social Media Addiction Scale (Andreassen et al., 2016) was used to measure social media addiction level of each participant, Big Five Inventory scale (John \& Srivastava, 1999) was used to measure openness level, short version of Values in Action Inventory of Strengths scale (Lee, Foo, Adams, Morgan, \& Frewen, 2015) was used to measure creativity level and social intelligence level, Eysenck Personality Questionnaire Revised-Abbreviated form (Karanci, Dirik, \& Yorulmaz, 2007) was used to measure neuroticism level, Rosenberg's Self-Esteem Scale (Buyukgungor, 2016) was used to measure self-esteem level, Satisfaction with Life Scale (Dagli \& Baysal, 2016) was used to measure life satisfaction level, short version of UCLA Loneliness Scale (Hays \& DiMatteo, 1987) was used to measure loneliness level, Perceived Stress Scale (Eskin, Harlak, Demirkıran, \& Dereboy, 2013) was used to measure stress level, and short version of Narcissistic Personality Inventory (Buyukgungor, 2016) was used to measure narcissism level of each participant.

\section{Findings}

Reliability Tests

After the arrangement of data, even though scales were directly retrieved from literature, reliability tests were applied. According to Cronbach (1951), Cronbach's alpha value of each scale should be greater than .70 to state that the scale is reliable. Reliability test results seen in Table 2, illustrate that all scales provide reliability condition with Cronbach's alpha values above .70 . 
Table 2. Reliability analysis of scales

\begin{tabular}{lcc}
\hline Variables & $\begin{array}{c}\text { Number of } \\
\text { Items }\end{array}$ & $\begin{array}{c}\text { Cronbach's } \\
\text { Alpha }\end{array}$ \\
\hline Social Media & 6 & .773 \\
Addiction & 10 & .800 \\
Openness & 8 & .874 \\
Loneliness & 6 & .822 \\
Neuroticism & 5 & .893 \\
Creativity & 14 & .890 \\
Stress & 10 & .733 \\
Self-Esteem & 5 & .706 \\
Social Intelligence & 5 & .839 \\
Life Satisfaction & 16 & .703 \\
Narcissism & & \\
\hline
\end{tabular}

\section{Normality Tests}

Normality is one of the other prerequisites for many statistical tests. Skewness and kurtosis values are checked to see whether the data is normally distributed or not. According to Tabachnick and Fidell (2013), skewness and kurtosis values should be between -1.5 and 1.5 to support normality assumption of data. All skewness and kurtosis values in Table 3 are between this range. Therefore, it can be stated that data collected by the questionnaire is normally distributed for each variable.

Table 3. Normality test results of data

\begin{tabular}{lcc}
\hline Variables & Skewness & Kurtosis \\
\hline Social Media & .318 & -.275 \\
Addiction & -.355 & .354 \\
Openness & .814 & .459 \\
Loneliness & .115 & .427 \\
Neuroticism & -.489 & .567 \\
Creativity & .460 & .163 \\
Stress & -.545 & -.176 \\
Self-Esteem & -.414 & 1.186 \\
Social Intelligence & -.164 & -.371 \\
Life Satisfaction & .382 & .341 \\
Narcissism & & \\
\hline
\end{tabular}

Descriptive Statistics

According to Table 4, 357 of 506 participants were female whereas 149 of them were male. They are in different age ranges, have different education levels and different income 
status. Almost half of the participants were single and another half of them were married. Moreover, participants worked in many different sectors which are shown in Table 5.

Table 4. Demographic profiles of the participants

\begin{tabular}{|c|c|c|c|c|c|c|}
\hline Gender & Female & Male & & & & \\
\hline Frequency & 357 & 149 & & & & \\
\hline Percent & 70.6 & 29.4 & & & & \\
\hline Age & $18-24$ & $25-29$ & $30-49$ & $50-64$ & $>64$ & \\
\hline Frequency & 147 & 127 & 153 & 76 & 3 & \\
\hline Percent & 29.1 & 25.1 & 30.2 & 15 & 0.6 & \\
\hline Marital Status & Single & Married & & & & \\
\hline Frequency & 283 & 223 & & & & \\
\hline Percent & 55.9 & 44.1 & & & & \\
\hline $\begin{array}{l}\text { Education } \\
\text { Level }\end{array}$ & $\begin{array}{c}\text { Primary } \\
\text { School } \\
\text { Graduate } \\
\end{array}$ & $\begin{array}{c}\text { High } \\
\text { School } \\
\text { Graduate } \\
\end{array}$ & $\begin{array}{l}\text { Undergraduat } \\
\text { e Student }\end{array}$ & $\begin{array}{l}\text { Bachelor's } \\
\text { Degree }\end{array}$ & $\begin{array}{c}\text { Graduate } \\
\text { / PhD } \\
\text { Student } \\
\end{array}$ & $\begin{array}{c}\text { Graduate/ } \mathrm{PhD} \\
\text { Degree }\end{array}$ \\
\hline Frequency & 14 & 58 & 113 & 203 & 81 & 37 \\
\hline Percent & 2.8 & 11.5 & 22.3 & 40.1 & 16 & 7.3 \\
\hline Income & $\begin{array}{c}\text { Less than } \\
1600 \mathrm{TL}\end{array}$ & $\begin{array}{c}1600- \\
3200 \mathrm{TL}\end{array}$ & $3201-4800 \mathrm{TL}$ & 4801-6400 TL & $\begin{array}{c}\text { More than } \\
6400 \mathrm{TL}\end{array}$ & \\
\hline Frequency & 32 & 102 & 101 & 92 & 179 & \\
\hline Percent & 6.3 & 20.2 & 20 & 18.2 & 35.4 & \\
\hline
\end{tabular}

Table 5. Distribution of categorized occupations of the participants

\begin{tabular}{lcc}
\hline Occupation & Frequency & Percent \\
\hline Architecture & 11 & 2.2 \\
Arts \& Communication & 11 & 2.2 \\
Business Management & 29 & 5.7 \\
Education & 62 & 12.3 \\
Engineering & 38 & 7.5 \\
Finance & 12 & 2.4 \\
Government \& Public Administrations & 28 & 5.5 \\
Health Science & 39 & 7.7 \\
Housewife & 35 & 6.9 \\
Human Services & 35 & 6.9 \\
Information Technology & 14 & 2.8 \\
Law & 15 & 3 \\
Manufacturing & 10 & 2 \\
Marketing & 11 & 2.2 \\
Retired & 18 & 3.6 \\
Student & 108 & 21.3 \\
Transportation, Distribution \& Logistics & 24 & 4.7 \\
\hline
\end{tabular}


Daily spending times on social networking sites and number of social media accounts check of the participants were questioned to gain knowledge about social media usage habits of the participants. Results show that duration and check time frequencies are different from each other. For example, some people might check their accounts less than six times a day because they are busy during the day, but they might spend hours nonstop on social media before they go to sleep. Therefore, both two conditions play significant role in understanding social media usage habits of the participants. Distribution of daily spending duration of the participants and how many times participants check their social media accounts on SNS can be seen in Table 6.

Table 6. Distribution of daily spending duration and check times of the participants

\begin{tabular}{lccccc}
\hline Duration & $0-1$ Hour & $2-3$ Hours & $4-5$ Hours & More than 5 Hours & \\
\hline Frequency & 131 & 269 & 67 & 39 & \\
Percent & 25.9 & 53.2 & 13.2 & 7.7 & More than 30 \\
\hline Check Time & Less than 6 & $6-10$ & $11-20$ & $21-30$ & 59 \\
\hline Frequency & 116 & 156 & 111 & 64 & 11.7 \\
Percent & 22.9 & 30.8 & 21.9 & 12.6 & 11.7 \\
\hline
\end{tabular}

According to Table 7, the most used social media platform was WhatsApp. Following WhatsApp, YouTube, Instagram, and Facebook were the most preferable social networking sites. Twitter, LinkedIn, Spotify, Pinterest, and Skype were also favorable platforms for some of the participants.

Table 7. Frequencies of commonly used social media platforms

\begin{tabular}{lcc}
\hline Social Networking Sites & Frequency & Percent \\
\hline Facebook & 348 & 68.8 \\
WhatsApp & 493 & 97.4 \\
Twitter & 227 & 44.9 \\
Instagram & 401 & 79.2 \\
LinkedIn & 200 & 39.5 \\
Swarm & 31 & 6.1 \\
YouTube & 413 & 81.6 \\
Periscope & 10 & 2 \\
Snapchat & 83 & 16.4 \\
Skype & 114 & 22.5 \\
Tinder & 12 & 2.4 \\
Pinterest & 119 & 23.5 \\
Spotify & 175 & 34.6
\end{tabular}




\begin{tabular}{lcc} 
Tumblr & 29 & 5.7 \\
Reddit & 19 & 3.8 \\
Flickr & 6 & 1.2 \\
Other & 19 & 3.7 \\
\hline
\end{tabular}

Independent Sample t-tests and One-way ANOVA

Independent sample t-tests and one-way analysis of variance tests were applied. According to independent sample t-test results, social media addiction level of female participants is relatively higher than males' and singles relatively shows more tendency to social media than married people. Also, a significant main effect of age on social media addiction was detected in ANOVA. Bonferroni test was applied to figure out which groups created this significant difference. It was revealed that young participants were more addicted than old ones. Besides, in terms of education levels of the participants, there is a significant difference only between two groups which are group of undergraduate students and group which consist of the participants who have Graduate or $\mathrm{PhD}$ degree. On the other hand, there is no significant difference among the income level groups in terms of social media addiction degree. When the social media usage habits were evaluated, it was seen that increase in daily spending time on SNS and increase in the number of checks of social media accounts increased social media addiction level. By comparing means of occupational groups in terms of social media addiction, it can be said that people working in law area and students are relatively more addicted to social media platforms than the others.

Furthermore, social media addiction level of the participants working in marketing area and participants working in finance sector are relatively less addicted to social media platforms. However, occupational groups are not significantly different from each other in terms of social media addiction level, since $\mathrm{p}$ value is greater than .05 . Table 8 shows the mean values (over 5) of demographic variables except occupational group and their independent sample t-test or ANOVA results in terms of social media addiction level and Table 9 illustrates mean values (over 5) of occupational groups and their independent sample t-test or ANOVA results in terms of social media addiction level of the participants. 
Table 8. Demographic group differences in terms of social media addiction

\begin{tabular}{|c|c|c|c|c|c|c|}
\hline Sig. (2-tailed) & Female & Male & & & & \\
\hline $.000 *$ & 2.55 & 2.19 & & & & \\
\hline Sig. & $18-24$ & $25-29$ & $30-49$ & $50-64$ & $>64(3)$ & \\
\hline $.000^{*}$ & 2.67 & 2.54 & 2.29 & 2.15 & 2.33 & \\
\hline Sig. (2-tailed) & Single & Married & & & & \\
\hline $.000^{*}$ & 2.57 & 2.29 & & & & \\
\hline Sig. & $\begin{array}{l}\text { Primary } \\
\text { School } \\
\text { Graduate }\end{array}$ & $\begin{array}{c}\text { High } \\
\text { School } \\
\text { Graduate }\end{array}$ & $\begin{array}{c}\text { Undergraduate } \\
\text { Student }\end{array}$ & $\begin{array}{l}\text { Bachelor's } \\
\text { Degree }\end{array}$ & $\begin{array}{c}\text { Graduate / } \\
\text { PhD Student }\end{array}$ & $\begin{array}{c}\text { Graduate / } \\
\text { PhD Degree }\end{array}$ \\
\hline $.002^{* *}$ & 2.14 & 2.34 & 2.65 & 2.39 & 2.55 & 2.13 \\
\hline Sig. & $\begin{array}{l}\text { Less than } \\
1600 \mathrm{TL}\end{array}$ & $\begin{array}{c}1600-3200 \\
\text { TL }\end{array}$ & $3201-4800 \mathrm{TL}$ & $\begin{array}{l}4801-6400 \\
\text { TL }\end{array}$ & $\begin{array}{l}\text { More than } \\
6400 \mathrm{TL}\end{array}$ & \\
\hline .152 & 2.57 & 2.53 & 2.54 & 2.41 & 2.34 & \\
\hline Sig. & 0-1 Hour & 2-3 Hours & 4-5 Hours & $\begin{array}{l}\text { More than } \\
5 \text { Hours }\end{array}$ & & \\
\hline $.000^{*}$ & 2.03 & 2.45 & 2.79 & 2.23 & & \\
\hline Sig. & Less than 6 & $6-10$ & $11-20$ & $21-30$ & More than 30 & \\
\hline $.000^{*}$ & 2.08 & 2.37 & 2.52 & 2.69 & 2.94 & \\
\hline
\end{tabular}

* significant at $1 \%$ alpha level; ${ }^{* *}$ significant at $5 \%$ alpha level

Table 9. Occupational group differences in terms of social media addiction

\begin{tabular}{lcc}
\hline Occupation & Mean (Over 5) & Sig. \\
\hline Architecture & 2.58 \\
Arts \& Communication & 2.33 & \\
Business Management & 2.57 & \\
Education & 2.50 \\
Engineering & 2.23 \\
Finance & 2.18 \\
Government \& Public & 2.38 \\
Administrations & 2.47 \\
Health Science & 2.25 \\
Housewife & 2.38 \\
Human Services & 2.46 \\
Information Technology & 2.69 \\
Law & 2.32 \\
Manufacturing & 1.92 \\
Marketing & 2.36 \\
Retired & 2.68 \\
Student & 2.20 \\
Transportation, & \\
Distribution \& Logistics &
\end{tabular}




\section{Correlation Analyses}

Correlation analyses based on the theoretical model of present study were applied to detect whether there is a significant correlation among the variables or not when they are just one factor. All correlations in the theoretical model except correlations between openness and social media addiction and between narcissism and social media addiction were found statistically significant at .05 alpha level. The correlation between openness and social media addiction can be acceptable for 90 percent confidence interval. However, there is no significant correlation between narcissism and social media addiction. Thus, although narcissism is a part of the theoretical framework of this study, it is excluded from the SEM analysis.

\section{Structural Equation Modeling}

Structural Equation Modeling was used in the analysis. According to Hair, Black, Babin and Anderson (2014), if the model includes more than seven constructs which is defined as total of dependent and independent variables, sample size should be at least 500 . In the present study, there were 506 participants. Therefore, the number of respondents was appropriate to use SEM.

\section{Confirmatory Factor Analysis}

The first step of SEM is confirmatory factor analysis. A measurement model including nine latent variables named openness, perceived stress, life satisfaction, creativity, social intelligence, loneliness, neuroticism, self-esteem and social media addiction was created to see standardized regression weights of each item of all factors by using maximum likelihood method. Factor loadings based on this measurement model were estimated. The sample of this study consists of more than 350 people. Therefore, factor loadings should be at least .30 to be significant, but .50 or greater is more acceptable for significance (Hair et al., 2014). Thus, some items which had a value smaller than .50 were removed from the model. After deleting these items, measurement model was revised twice until there were no items which had lower factor loading value. Measurement model shown in Figure 2 was used as a measurement model of the SEM analysis. 


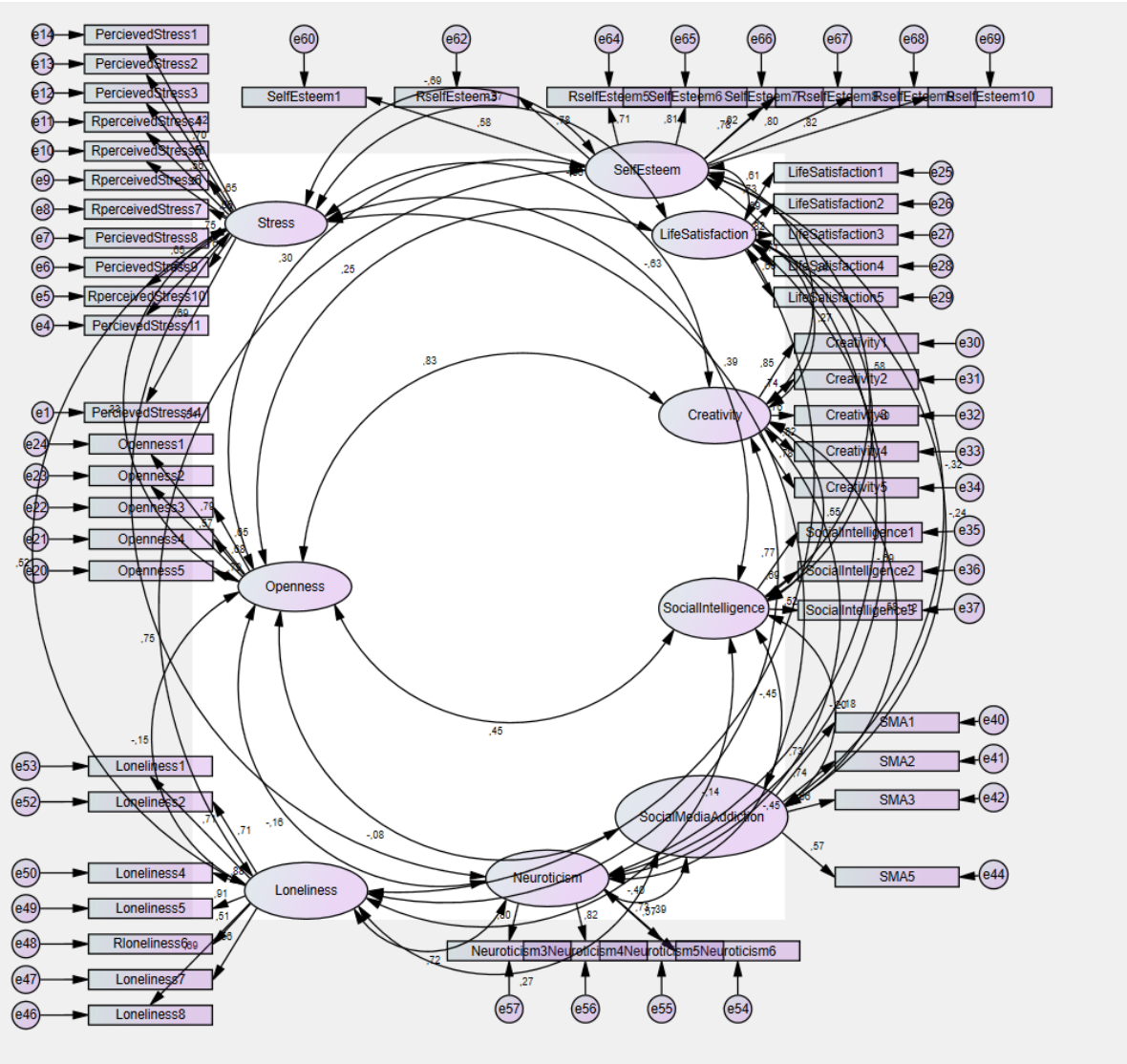

Figure 2. Measurement model

In this model, chi-square and degrees of freedom as goodness of fit indices, root mean square error of approximation (RMSEA) and normed chi-square as absolute fit measures, and comparative fit index as an incremental fit index were used to evaluate fitness of the model. According to Hair and colleagues (2014), RMSEA is one of the most appropriate methods to measure fitness of the models especially for large samples which includes more than 500 participants. If the sample consists of more than 500 people, the value of RMSEA should be between .03 and .08 to say that the model is acceptable. Besides, normed chisquare should be equal to or smaller than three to mention better-fitting model. Moreover, if the value of CFI which changes from zero to one is above .90, it can be stated that this model fits greatly with the data. According to Table 10 which indicates measurement model fit summary, RMSEA value is .056 which is between .03 and .08 . Normed chi-square was found as 2.60 which is smaller than 3.0. Therefore, these values are an acceptable fit value. For CFI value, acceptable value is usually above .90 . In this model, CFI is .86 which is so close to .90 . Thus, it might be said that this measurement model ensures prevalent fit to the data. 
Table 10. Measurement model fit summary

\begin{tabular}{ccccc}
\hline \multicolumn{2}{c}{ Goodness of Fit Indices } & \multicolumn{2}{c}{ Absolute Fit Measures } & Incremental Fit Indices \\
\hline \multirow{2}{*}{ Chi-Square } & Degrees of Freedom & RMSEA & Normed Chi- & CFI \\
3359.417 & 1289 & .056 & 2.60 & .858 \\
\hline
\end{tabular}

\section{Structural Model}

Structural model which is the second step of SEM analysis designates the relationships between the independent and dependent variables as a path model. Structural model of current study is demonstrated in Figure 3.

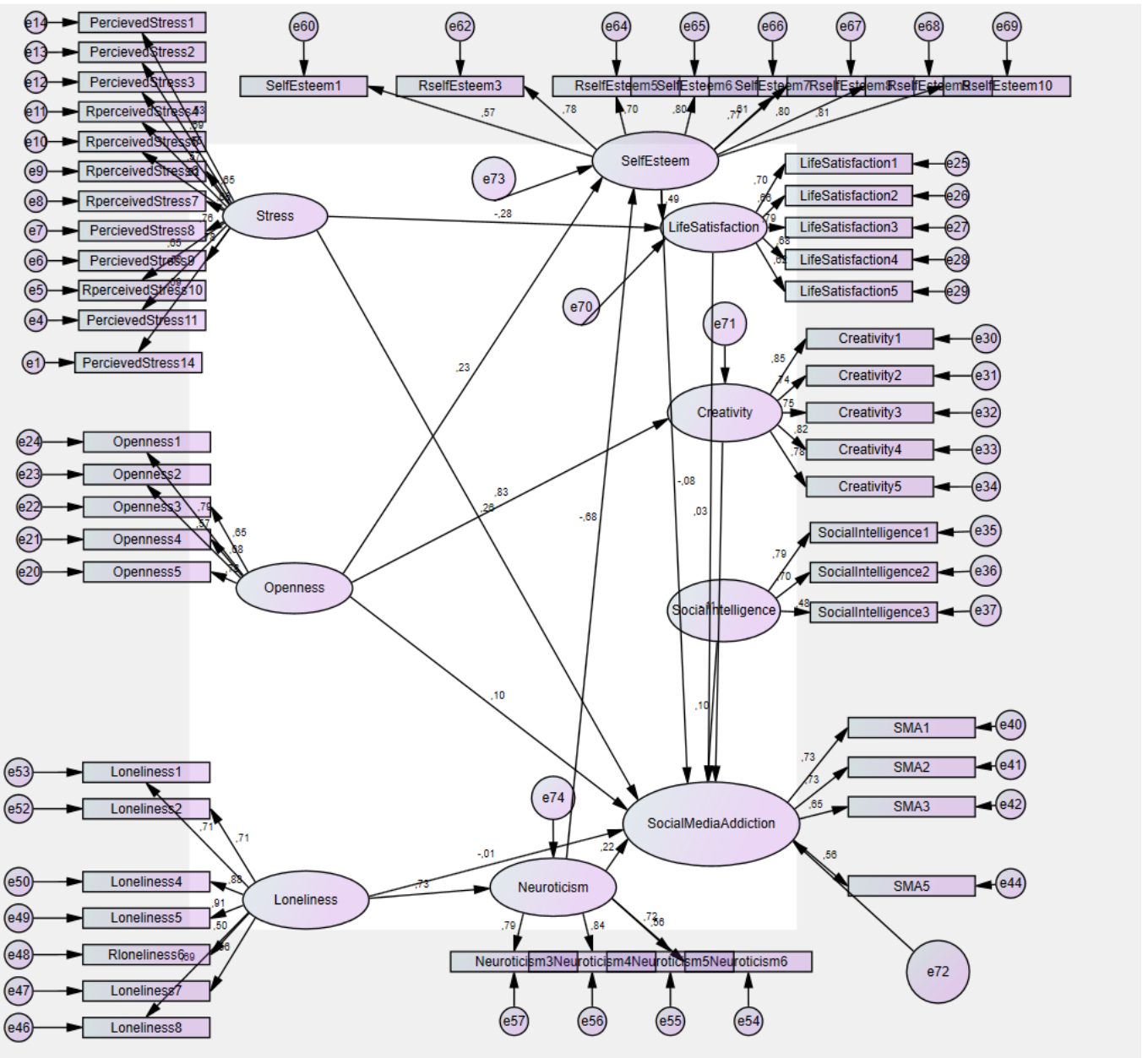

Figure 3. Structural model

Structural model validity was checked by evaluating a normed chi-square, RMSEA and CFI values of the model. According to Table 11 which shows structural model fit summary, RMSEA value (.064) is in acceptable fit range which is between .03 and .08 . Normed chi-square value (3.07) can be also acceptable because it is almost 3.0. CFI value is equal to .814 which is a little bit smaller than commonly used acceptable range (.90). Overall, it might be said that structural model meets the requirements of model fit. 
Table 11. Structural model fit summary

\begin{tabular}{lcccc}
\hline Goodness of Fit Indices & \multicolumn{2}{c}{ Absolute Fit Measures } & Incremental Fit Indices \\
\hline Chi-Square & Degrees of Freedom & RMSEA & Normed Chi-Square & CFI \\
4020.352 & 1311 & .064 & 3.067 & .814 \\
\hline
\end{tabular}

Standard regression weights of variables are shown in Table 12. Among the independent variables of present study, openness has a significant positive impact on creativity and self-esteem, self-esteem has a significant positive impact on life satisfaction, loneliness has a significant positive impact on neuroticism, neuroticism has a significant negative impact on self-esteem, stress has a significant negative impact on life satisfaction, stress has a significant positive impact on social media addiction. Besides, it is seen that neuroticism have a significant positive impact on social media addiction degree of the participants at the .05 alpha level. Moreover, if the results are evaluated in $90 \%$ confidence interval, it can be deduced that social intelligence has also significant positive impact on social media addiction. However, openness, creativity, self-esteem, loneliness, and life satisfaction do not play a significant role on social media addiction level of the participants.

Table 12. Standardized regression weights of variables and hypotheses

\begin{tabular}{|c|c|c|c|c|c|}
\hline Hno & \multicolumn{3}{|c|}{ Relationships between Variables } & Regression Weights & $\mathrm{p}$ Value \\
\hline $\mathrm{H} 1$ & \multirow{3}{*}{ Openness } & \multirow{3}{*}{$--->$} & Creativity & .833 & .000 \\
\hline $\mathrm{H} 2$ & & & Self-Esteem & .234 & .000 \\
\hline $\mathrm{H} 3$ & & & Social Media Addiction & .102 & .405 \\
\hline $\mathrm{H} 4$ & Creativity & $--->$ & Social Media Addiction & -.106 & .365 \\
\hline H5 & \multirow{2}{*}{ Self-Esteem } & \multirow{2}{*}{$-->$} & Life Satisfaction & .491 & .000 \\
\hline H6 & & & Social Media Addiction & -.079 & .375 \\
\hline $\mathrm{H} 7$ & \multirow{2}{*}{ Loneliness } & \multirow{2}{*}{$--->$} & Neuroticism & .734 & .000 \\
\hline $\mathrm{H} 8$ & & & Social Media Addiction & -.010 & .908 \\
\hline H9 & \multirow{2}{*}{ Neuroticism } & \multirow{2}{*}{$--->$} & Self-Esteem & -.676 & .000 \\
\hline $\mathrm{H} 10$ & & & Social Media Addiction & .220 & .049 \\
\hline H11 & \multirow{2}{*}{ Stress } & \multirow{2}{*}{$--->$} & Life Satisfaction & -.279 & .000 \\
\hline $\mathrm{H} 12$ & & & Social Media Addiction & .260 & .000 \\
\hline H13 & Life Satisfaction & $--->$ & Social Media Addiction & .027 & .692 \\
\hline H14 & Social Intelligence & $-->$ & Social Media Addiction & .097 & .083 \\
\hline
\end{tabular}




\section{Discussion and Conclusion}

According to Kirik and colleagues (2015) and this study, daily spending time on SNS and the number of social media account checks are parallel to social media addiction. Even though Jaradat and Atyeh (2017) claimed that gender and age differences were not effective upon problematic social media usage. In present study, as well as the study of Andreassen and colleagues (2016), it was seen that social media addiction levels were relatively high for females and young people because of high level of technology adaptability and singles due to having a chance to meet someone special. Education level of the participants also affected their social media addiction level. However, significant difference among all groups was not detected in terms of social media addiction. Income status and occupations were found as ineffective variables in this study. According to Jaradat and Atyeh (2017), King et al. (1996) and this study, openness level of the participants played a significant role on their creativity level and self-esteem level of the participants (Amirazodi \& Amirazodi, 2011). Self-esteem level of people is a deterministic element for their life satisfaction level (Hawi \& Samaha, 2017). This consideration was supported by the current study. Another variable which affected life satisfaction significantly was stress. Longstreet and Brooks (2017) also showed the great negative impact of stress on life satisfaction. People who feel alone have higher level of neuroticism (Mund \& Neyer, 2019). As a supportive result, present study detected that loneliness caused neuroticism. Moreover, it was seen that neuroticism was one of the main reasons for low level of self-esteem. According to some research, increase in neuroticism level of people leads to decrease in their self-esteem level (Amirazodi \& Amirazodi, 2011).

One of the main findings was that openness did not have an impact on social media addiction when all behavioral factors mentioned before were taken into consideration as a model, although some studies claimed that social media was an attractive environment for people who had a high openness level (Correa et al., 2010; Jaradat \& Atyeh, 2017). Creativity was another debating issue. In research by Lee and Hong (2016), high level of creativity contributed to social media addiction. However, Kircaburun and colleagues (2018) found that creativity had a negative influence on problematic social media usage. According to the current research, creativity has neither a positive nor a negative significant impact on social media addiction. In literature, there is a consensus about that self-esteem is significantly negatively correlated with excessive social media usage (Bozoglan et al., 2013; Hawi \& 
Savacı, Kutlu \& Özen

Samaha, 2017; Kim \& Davis, 2009; Niemz et al., 2005; Vogel et al., 2014). On the other hand, in the present study, even though according to results of correlation analysis, significant negative association between self-esteem and social media addiction was detected, SEM analysis showed that self-esteem level did not play a significant role on social media addiction when it was evaluated with the other factors. Researchers have a common insight not only for the influence of self-esteem but also for the impact of loneliness on social media addiction. According to researchers, loneliness leads to spending over time on social media platforms which causes social media addiction (Bozoglan et al., 2013; Engelberg \& Sjoberg, 2004; Hardie \& Tee, 2007; Liu \& Baumeister, 2016; Satici, 2019). However, as well as selfesteem, the results of SEM analysis indicated that loneliness did not have a significant impact on social media addiction. Although some study argued that neuroticism affected social media addiction negatively (Jaradat \& Atyeh, 2017), the results of this study and some research illustrated that neuroticism had a significant positive impact on social media addiction (Cao \& Su, 2007; Hardie \& Tee, 2007). One of the other factors which had a significant positive impact on social media addiction was stress. According to some studies, people show a tendency to use social media when they are stressful to eliminate stress (Longstreet \& Brooks, 2017; Sriwilai \& Charoensukmongkol, 2016). While some researchers claimed that one of the main reasons for social media addiction was low life satisfaction (Longstreet \& Brooks, 2017), interestingly Valenzuela et al. (2009) detected that people who had high level of life satisfaction used Facebook more than people who had low life satisfaction level. Nevertheless, Bozoglan et al. (2013), Hawi and Samaha (2017) and the present study indicated that there was no significant relationship directly between life satisfaction and social media addiction. Several studies claimed that narcissism was one of the most effective factors which triggered social media addiction (Andereassen et al., 2016; Casale \& Fioravanti, 2018; Hawi \& Samaha, 2017; Liu \& Baumeister, 2016). However, correlation results of this study indicated that there was no correlation between narcissism and social media addiction.

Social intelligence is the ability how people manage their relationships in any environment with any person (Baron-Cohen et al., 1999). By looking at this definition, it is clearly seen that social media, which is an environment that consists of several kinds of people, is substantially related to social intelligence. Therefore, social intelligence variable was involved in this research, even though there was not so much knowledge about 
associations between social intelligence and social media addiction in literature. The results of this study showed that social intelligence was one of the fundamental factors of social media addiction. It was seen that people who had high social intelligence level were more addicted to social media.

In today's world, social media, which brings people together by altering communicating and socializing methods, has become an indispensable part of people's lives (Sriwilai \& Charoensukmongkol, 2016). From day to day, the rate of social media usage is rapidly increasing (Jaradat \& Atyeh, 2017). This increase leads to social media addiction that shows any type of addiction symptoms such as withdrawal, emotional imbalance, and so on (Hawi \& Samaha, 2017). There are several factors for people to be addicted to social media. As well as demographical features, characteristics of people have a great importance on social media addiction (Bozoglan et al., 2013; Hamid et al., 2015; Hardie \& Tee, 2007; Hawi \& Samaha, 2017; Jaradat \& Atyeh, 2017; Young \& Rodgers, 1998). Therefore, in this research, the impacts of specific behavioral factors on social media addiction were focused on. As a result of the current study, it was found that high level of stress, neuroticism and social intelligence increased social media addiction level. However, results indicated that social media addiction levels of the participants were not affected from their openness, creativity, self-esteem, loneliness, life satisfaction, and narcissism levels. It was also discovered that openness level of the participants affected positively both their creativity and self-esteem levels which was also affected from their neuroticism level negatively. Besides, participants' self-esteem level had a positive impact on their life satisfaction degree that was influenced from the stress level negatively. Moreover, it was revealed that loneliness level of the participants had a favorable impact on their neuroticism level.

However, this study is not without limitations. The survey was distributed through the social media friends of the authors using convenience sampling. A better sampling method can be used in future studies especially for the occupational groups. Also, structural equation modeling group analysis can be applied as a further study.

\section{Acknowledgement}

An earlier version of this paper was presented at the International Eurasian Conference on Educational \& Social Studies, Antalya-Turkey (October 22-24, 2021). The data used in this study was confirmed by the researchers that it belongs to the years before 2020. 
Author Contribution Statement

Gönül Zeynep SAVACI: Conceptualization, methodology, implementation, data analysis, writing and editing.

Birgül KUTLU: Conceptualization, methodology, consultancy and control preliminary draft writing and editing.

Çağla ÖZEN: Review-writing and editing

\section{References}

Amichai-Hamburger, Y., \& Ben-Artzi, E. (2003). Loneliness and Internet use. Computers in Human Behavior, 19(1), 71-80.

Amirazodi, F., \& Amirazodi, M. (2011). Personality traits and self-esteem. Procedia Social and Behavioral Sciences, 29, 713-716. doi: 10.1016/j.sbspro.2011.11.296

Andreassen, C. S., Billieux, J., Griffiths, M. D., Kuss, D. J., Demetrovics, Z., Mazzoni, E., \& Pallesen, S. (2016). The relationship between addictive uses of social media and video games and symptoms of psychiatric disorders: A large-scale cross-sectional study. Psychology of Addictive Behaviours, 30(2), 252-262.

Appel, G., Grewal, L., Hadi, R., \& Stephen, A. T. (2020). The future of social media in marketing. Journal of the Academy of Marketing Science, 48(1), 79-95.

Arslan, A. (2020). Üniversite öğrencilerinin dijital bağımlılık düzeylerinin çeşitli değişkenler açısından incelenmesi [Determination of the digital addiction levels of students university according to various variables]. International e-Journal of Educational Studies (IEJES), 4(7), 27-41. DOI: 10.31458/iejes.600483.

Baron-Cohen, S., Ring, H. A., Wheelwright, S., Bullmore, E. T., Brammer, M. J., Simmons, A., \& Williams, S. C. (1999). Social intelligence in the normal and autistic brain: An fMRI study. European Journal of Neuroscience, 11(6), 1891-1898.

Bozoglan, B., Demirer, V., \& Sahin, I. (2013). Loneliness, self-esteem, and life satisfaction as predictors of Internet addiction a cross-sectional study among Turkish university students. Scandinavian Journal of Psychology, 54(4), 313-319.

Buyukgungor, A. (2016). The Turkish adaptation of the pathological narcissism inventory (PNI). (Unpublished master's thesis). Bahcesehir University, Istanbul.

Cao, F., \& Su, L. (2007). Internet addiction among Chinese adolescents: Prevalence and psychological features. Child: Care, Health and Development, 33(3), 275-281.

Casale, S., \& Fioravanti, G. (2018). Why narcissists are at risk for developing Facebook addiction: The need to be admired and the need to belong. Addictive Behaviors, 76, 312-318. doi: 10.1016/j.addbeh.2017.08.038

Casale, S., Rugai, L., \& Fioravanti, G. (2018). Exploring the role of positive metacognitions in explaining the association between the fear of missing out and social media addiction. Addictive Behaviours, 85, 83-87. doi: 10.1016/j.addbeh.2018.05.020 
Cizmeci, E. (2017). Disconnected, though satisfied: Phubbing behavior and relationship satisfaction. The Turkish Online Journal of Design, Art and Communication, 7(2), 364375 .

Correa, T., Hinsley, A. W., \& De Zuniga, H. G. (2010). Who interacts on the Web? The intersection of users' personality and social media use. Computers in Human Behavior, 26(2), 247-253.

Cronbach, L. J. (1951). Coefficient alpha and the internal structure of tests. Psychometrika, 16(3), 297-334.

Dagli, A., \& Baysal, N. (2016). Adaptation of the satisfaction with life scale into Turkish: The study of validity and reliability. Electronic Journal of Social Sciences, 15(59), 1250-1262.

Engelberg, E., \& Sjoberg, L. (2004). Emotional intelligence, affect intensity, and social adjustment. Personality and Individual Differences, 37(3), 533-542.

Eskin, M., Harlak, H., Demirkıran, F. \& Dereboy, C. (2013). The adaptation of the perceived stress scale into Turkish: A reliability and validity analysis. New Symposium Journal, 51(3), 132-140.

Genc, Y. E. (2015). Social media usage of college students and its impact on their buying behavior. (Unpublished master's thesis). İzmir Kâtip Çelebi University, Izmir.

Hair, J. F. Jr., Black, W. C., Babin, B. J., \& Anderson, R. E. (2014). Multivariate data analysis, Seventh edition. Harlow: Pearson Education Limited.

Hamid, N. A., Ishak, M. S., \& Yazam, S. S. N. M. (2015). Facebook, YouTube and Instagram: Exploring their effects on undergraduate students' personality traits. The Journal of Social Media in Society, 4(2), 138-165.

Hardie, E., \& Tee, M. Y. (2007). Excessive Internet use: the role of personality, loneliness and social support networks in Internet addiction. Australian Journal of Emerging Technologies and Society, 5(1), 34-47.

Hawi, N. S., \& Samaha, M. (2017). The relations among social media addiction, self-esteem, and life satisfaction in university students. Social Science Computer Review, 35(5), 576586.

Hays, R. D., \& DiMatteo, M. R. (1987). A short-form measure of loneliness. Journal of Personality Assessment, 51(1), 69-81.

Jaradat, M. I., \& Atyeh, A. J. (2017). Do personality traits play a role in social media addiction? Key considerations for successful optimized model to avoid social networking sites addiction: a developing country perspective. International Journal of Computer Science and Network Security, 17(8), 120-131.

Johansson, A., \& Gotestam, G. (2004). Internet addiction characteristics of a questionnaire and prevalence in Norwegian youth 12-18 years. Scandinavian Journal of Psychology, 45(3), 223-229.

John, O. P., \& Srivastava, S. (1999). The Big-Five trait taxonomy: History, measurement, and theoretical perspectives. Handbook of Personality: Theory and Research, 2, 102-138. 
Karanci, A. N., Dirik, G., \& Yorulmaz, O. (2007). Reliability and validity studies of Turkish translation of Eysenck personality questionnaire revised abbreviated. Turkish Journal of Psychiatry, 18(3), 254-261.

Khan, A. S., Rahman, A., \& Qazi, L. T. (2016). The relationship between internet usage, socioeconomic status, subjective health and social status. Business $\mathcal{E}$ Economic Review, 8(SE), 67-82.

Khan, S. F., Ullah, F., Khan, M. K., Jan, A., Raza, S., \& Shah, H. (2016). Effect of social media addiction on compliance in the patients of district Bannu, Khyber PakhtunKhwa. International Journal of Basic Medical Sciences and Pharmacy (IJBMSP), 6(2), 21-25.

Kirik, A. M., Arslan, A., Cetinkaya, A., \& Gul, M. (2015). A quantitative research on the level of social media addiction among young people in Turkey. International Journal of Science Culture and Sport (IntJSCS), 3(3), 108-122. doi:10.14486/IntJSCS444

Kim, H. K., \& Davis, K. E. (2009). Toward a comprehensive theory of problematic Internet use: Evaluating the role of self-esteem, anxiety, flow, and the self-rated importance of Internet activities. Computers in Human Behavior, 25(2), 490-500.

King, L. A., McKee Walker, L., \& Broyles, S. J. (1996). Creativity and the five-factor model. Journal of Research in Personality, 30(2), 189-203.

Kircaburun, K., \& Griffiths, M. D. (2018). Instagram addiction and the big five of personality: The mediating role of self-liking. Journal of Behavioral Addictions, 7(1), 158-170.

Kircaburun, K., Griffiths, M. D., Sahin, F., Bahtiyar, M., Atmaca, T., \& Tosuntas, S. B. (2018). The mediating role of self/everyday creativity and depression on the relationship between creative personality traits and problematic social media use among emerging adults. International Journal of Mental Health Addiction, 7(1), 1-12.

Kwon, M., Kim, D. J., Cho, H., \& Yang, S. (2013). The smartphone addiction scale: Development and validation of a short version for adolescents. PLOS ONE, 8(12), e83558. doi:10.1371/journal.pone.0083558

Lee, J., \& Hong, I. B. (2016). Predicting positive user responses to social media advertising: The roles of emotional appeal, informativeness, and creativity. International Journal of Information Management, 36(3), 360-373.

Lee, J. N. T., Foo, K. H., Adams, A., Morgan, R., \& Frewen, A. (2015). Strengths of character, orientations to happiness, life satisfaction and purpose in Singapore. Journal of Tropical Psychology, 5(e2), 1-21. doi:10.1017/jtp.2015.2

Liu, D., \& Baumeister, R. F. (2016). Social networking online and personality of self-worth: A meta-analysis. Journal of Research in Personality, 64, 79-89.

Longstreet, P., \& Brooks, S. (2017). Life satisfaction: A key to managing Internet \& social media addiction. Technology in Society, 50, 73-77. doi: 10.1016/j.techsoc.2017.05.003

Montag, C., Bey, K., Sha, P., Li, M., Chen, Y. F., Liu, W. Y., ... \& Reuter, M. (2015). Is it meaningful to distinguish between generalized and specific Internet addiction? Evidence from a cross-cultural study from Germany, Sweden, Taiwan and China. Asia-Pacific Psychiatry, 7(1), 20-26. 
Mund, M., \& Neyer, F. J. (2019). Loneliness effects on personality. International Journal of Behavioral Development, 43(2), 136-146. doi:10.1177/0165025418800224

Niemz, K., Griffiths, M., \& Banyard, P. (2005). Prevalence of pathological Internet use among university students and correlations with self-esteem, the general health questionnaire (GHQ), and disinhibition. CyberPsychology \& Behavior, 8(6), 562-570.

Ozer, O. (2020). Smartphone addiction and fear of missing out: does smartphone use matter for students' academic performance?. Journal of Computer and Education Research, 8(15), 344- 355. DOI: 10.18009/jcer.696481

Priyadarshana, G. L. S., Yatigammana, M. R. K. N., \& Sarathchandra, K. S. H. (2017). Factors determining the addiction of Sri Lankan software engineers towards social networks with special reference to Facebook. Entrepreneurship and Innovation Management Journal, 5(1), 29-41.

Satici, S. A. (2019). Facebook addiction and subjective well-being: A study of the mediating role of shyness and loneliness. International Journal of Mental Health and Addiction, 17(1), 41-55.

Savci, M., \& Aysan, F. (2017). Social-emotional model of internet addiction. Psychiatry and Clinical Psychopharmacology, 27(4), 349-358.

Sriwilai, K., \& Charoensukmongkol, P. (2016). Face it, don't facebook it: Impacts of social media addiction on mindfulness, coping strategies and the consequence on emotional exhaustion. Stress and Health, 32(4), 427-434. doi:10.1002/smi.2637

Statista, (2018). Number of available applications in the Google Play store from December 2009 to December 2017. Statista, Retrieved May 14, 2018 from https://www.statista.com/statistics/266210/number-of-available-applications-in-thegoogle-play-store/.

Stepanikova, I., Nie, N. H., \& He, X. (2010). Time on the internet at home, loneliness, and life satisfaction: Evidence from panel time-diary data. Computers in Human Behaviour, 26(3), 239-338.

Tabachnick, B. G., \& Fidell, L. S. (2013). Using multivariate statistics, Sixth edition. Upper Saddle River: Pearson Education, Inc.

Valenzuela, S., Park, N., \& Kee, K. F. (2009). Is there social capital in a social network site? Facebook use and college students' life satisfaction, trust, and participation. Journal of Computer-Mediated Communication, 14, 875-901.

Van den Ejinden, R., Lemmens, J. S., \& Valkenburg, P. M. (2016). Social media disorder scale. Computers in Human Behaviour, 61, 478-487. doi: 10.1016/j.chb.2016.03.038

Vogel, E. A., Rose, J. P., Roberts, L. R., \& Eckles, K. (2014). Social comparison, social media, and self-esteem. Psychology of Popular Media Culture, 3(4), 206-222.

Wang, Y., Niiya, M., Mark, G., Reich, S. M., \& Warschauer, M. (2015). Coming of age (digitally): An ecological view of social media use among college students. Proceedings of the 18th ACM Conference on Computer Supported Cooperative Work \& Social Computing (pp. 571-582). New York: ACM. 
Whang, L. S., Lee, S., \& Chang, G. (2003). Internet over-users' psychological profiles: A behavior sampling analysis on Internet addiction. CyberPsychology $\mathcal{E}$ Behavior, 6(2), 143-150. doi:10.1089/109493103321640338

Yen, J. Y., Ko, C. H., Yen, C. F., Wu, H. Y., \& Yang, M. J. (2007). The comorbid psychiatric symptoms of Internet addiction: attention deficit and hyperactivity disorder (ADHD), depression, social phobia, and hostility. Journal of Adolescent Health, 41(1), 93-98.

Young, K. S., \& Rodgers, R. C. (1998, April). Internet addiction: Personality traits associated with its development. In 69th annual meeting of the Eastern Psychological Association (pp. 40-50). Bradford: University of Pittsburgh.

JCER's Publication Ethics and Publication Malpractice Statement are based, in large part, on the guidelines and standards developed by the Committee on Publication Ethics (COPE). This article is available under Creative Commons CC-BY 4.0 license (https://creativecommons.org/licenses/by/4.0/) 